Claremont Colleges

Scholarship@ Claremont

Pomona Faculty Publications and Research

Pomona Faculty Scholarship

1-1-1999

\title{
Parallel Traditions: State Folk Dance Ensembles and Folk Dance in "The Field"
}

Anthony Shay

Pomona College

\section{Recommended Citation}

Shay, Anthony. “Parallel Traditions: State Folk Dance Ensembles, Presentational Folk Dance, and Folk Dance in the Field,” Dance Research Journal 31, no. 1 (Spring, 1999), pp. 29-56.

This Article is brought to you for free and open access by the Pomona Faculty Scholarship at Scholarship @ Claremont. It has been accepted for inclusion in Pomona Faculty Publications and Research by an authorized administrator of Scholarship @ Claremont. For more information, please contact scholarship@cuc.claremont.edu. 
Parallel traditions: State folk dance ensembles and folk dance in "The Field"

\title{
Shay, Anthony
}

Dance Research Journal; Spring 1999; 31, 1; ProQuest Research Library

pg. 29

\section{Parallel Traditions: State Folk Dance Ensembles and Folk Dance in "The Field"}

\author{
Anthony Shay
}

\section{Introduction}

In the $1950 \mathrm{~s}$, the world saw the birth, growth, and development of a new dance genre, the choreographic creations of the professional state folk dance ensemble (1). The genesis of what became a worldwide phenomenon of professional, semi-professional and amateur folk dance ensembles, with the notable exception of the capitalistic Western powers and Japan, began, in my opinion, in response to the extraordinary success of the Ensemble of Folk Dances of the Peoples of the Soviet Union, known in the West as the Moiseyev Dance Company, under the artistic direction of founder Igor Moiseyev. This ensemble was begun in 1937 at the onset of World War II, but its major impact began with the political reformation of the world in the aftermath of the war. During this period the U.S.S.R.'s direct political domination of Eastern Europe and popularity and influence in other regions of the world led to widespread emulation of the Soviet model of different types of institutions, including the formation of professional state-sponsored dance companies. This dance symbol became so crucial that a small nation like Bulgaria had seventeen professional folk song and dance ensembles by the 1980s (Ilieva 1994, 35).

All of these folk dance ensembles claim that individuals, often the choreographer or artistic director, conduct prodigious amounts of field research in order to present the most authentic choreographic products possible. Claims of authenticity loom large in the program notes, newspaper stories, and other publications that these companies generate. Nevertheless, because these professional companies clearly present an often highly stylized, carefully choreographed and staged genre of dance that differs from dances that are found among nonprofessional populations of villagers and tribes people, most dance researchers have shunned serious analyses of these companies as "unauthentic," "slick," and "theatrical" (2). This scholarly avoidance has created a crucial lacuna in dance research literature and consequently few studies which address the topic of ethnic/traditional/folk dance analyze or even mention that these highly visible and influential dance companies, which are seen by millions of enthusiastic viewers, exist.

Anthony Shay holds a Ph.D. in dance history and theory from the University of California, Riverside. He also holds masters degrees in anthropology, folklore and mythology, and library science. He is a five-time recipient of the National Endowment for the Arts choreographic fellowship and was an NEA resident artist in La Napoule, France. He currently serves as choreographer and artistic director of the AVAZ International Dance Theatre, a group he founded in 1977. 
In this introductory essay I put forth several concepts and elements that can be profitably examined before any meaningful analysis of these ensembles and their choreographic output can be properly addressed. These include issues of authenticity and representation, as well as the variety of social and technical restrictions and limitations-political, financial, artisticfaced by the artistic directors of these companies. Thus, the main intent of this essay is to establish a theoretical and methodological model for the study of professional and semi-professional state folk dance ensembles as well as the numerous amateur performing and exhibition groups that emulate the state dance companies.

I suggest that, regarding authenticity, many of the choreographic creations of several of these state ensembles are descended from the dance form which in classical ballet is known as "character dance," which Arkin and Smith in their essay characterize as "folk-derived" (1997, 12). In nineteenth-century character dance, Arkin and Smith observe that "anecdotal evidence suggests that folk dances were "balleticized" $(1997,54)$. I would go a step farther than Arkin and Smith and point out that the steps and movements of character dance often have no connection with dance in the field and yet ballet character dance characterizes the bulk of choreographic output of such twentieth-century folk dance companies as those of Igor Moiseyev, the Reda Company of Egypt, and Mazowsze of Poland. Such a dance form might be considered as what Hobsbawm and Ranger (1983) term an "invented tradition" (3). By contrast, other companies such as the Croatian State Ensemble, Lado, and the Dora Stratou Dancers of Greece are truly devoted to the inclusion of authentic elements of traditional life such as the use of musical instruments and vocal styles, costumes, and dance steps, movements, and the portrayal of customs and ritual. Thus the degree of authenticity utilized by each company varies widely. Unfortunately, scholars have produced little material in English about the choreographic creations of the various state dance ensembles to form an analytic comparison (4).

The time has arrived for a serious analysis of state folk dance ensembles and their relationship to the dancing found in village and tribal groups, which many dance ethnologists have addressed in great detail. This analysis and comparison of these two dance genres, the presentations of professional state dance ensembles and what I call the dancing in "the field," form an important area of dance research, especially since the changing political and cultural situation in Eastern Europe and the former Soviet Union challenges the existence and meaning of these companies and their relationship with traditional dance. Thus this essay, intended as an introduction to the study and analysis of the repertoires, staging, and choreographic strategies of national state ensembles, requires a discussion of "dance in the field," since all of the national companies claim connections with these field dance genres. These professional, semi-professional and often highly proficient amateur folk dance ensembles utilize varying degrees of choreographic and cultural elements their researchers found in the field for purposes of establishing claims of authenticity, a leitmotif which appears in all discussions of these ensembles. Other ensembles, such as the Moiseyev Dance Company, in spite of claims to authenticity, create works from non-traditional sources such as character dance, with little or no actual utilization of the folk traditions upon which they claim to base their work. Nahachewsky claims that in some cases these two traditions are developed in isolation from one another $(1994,74)$ and Al Faruqi (1987) points out that the "folk" dance of the Reda Company (which according to Saleh [1979] enjoyed dance advisors from the U.S.S.R.) is European, not Egyptian.

Just as importantly, through the politicization of folk and traditional dancing in many parts of the world, dancing in the field also exhibits a wide variety of staging and presentational techniques, some of which approach the theatricalization of presentations seen within

\section{Dance Research Journal 31/1 (Spring 1999)}


the repertoires of some national dance companies (5). While authenticity of presentation does form a topic of discussion in some studies of ethnic dance, I have found no systematic discussion of the wide scope of degrees of elaboration and theatrical elements which people in "the field" utilize for their own presentations. Nor has there been an investigation into the reasons behind the development of such elaborations of performance (6). Many studies of traditional dance forms are framed as if the traditions in the villages and tribal areas in the field have been unaffected by the presence of professional national folk dance companies. Choreographic and staging elements of the performances of national dance companies are often emulated by rural groups desirous of professionalizing their presentations, thus creating a dynamic cycle which encompasses the appropriation of cultural and choreographic elements from field to stage and a return to the field of presentational elements. I suggest that a productive way in which the study and comparison of these two types of performances, those for stage and those found in the field, might be best characterized is as "parallel traditions." Further, these parallel traditions can often approach one another in the use of "authentic" elements found in the choreographic output of the professional companies as well as in the degree of theatricalization found in "traditional" performances. I argue that these parallel traditions maintain obvious ties to one another, if only in claims to such ties with the field that companies such as Ballet Folklorico of Mexico and Moiseyev stress, and that they form separate genres. These genres differ from one another in important ways, such as the mode of transmission of the dances, use of improvisation, and the degree of separation from the represented traditions exhibited by professional folk dance performers. In many field traditions (Mexico, Middle East, Eastern Europe) the dances are characterized by a high degree of improvisation while the staged performances are standardized and set. To some degree, an interaction between the two genres takes place through various forms of contact such as research projects in the field, joint participation in folk festivals, the conscious appropriation of images and staging techniques appropriated by villagers to make their presentations "more attractive," as well as the acquisition of steps and figures from the field by choreographers from the performing companies. By utilizing the concept of parallel traditions, the dance researcher is not required to make invidious comparisons of authenticity and theatricality but rather she or he may view the two types of dance as related but separate genres. Giurchescu underscores this point:

It may be argued from a theoretical point of view, that vernacular folklore and staged folklore, exist in indivisible and unbroken continuity. However, considering the practice of symbol transformation and manipulation, it is necessary to formally segregate the socio-cultural processes of folklore from selected products (dances, music, costumes, etc.) which are performed in the framework of a spectacle (called folklorism or "fakelore"). (1994, 21)

Within these two general categories there also exist many "micro" parallel traditions. For example, when a group of villagers journeys to a nearby town or capital city to show their dances, they may make minor alterations or none at all. Perhaps members of a young people's dance club will show the dances of their grandparents' generation, which no longer constitute a living tradition, although they are certainly closer to that tradition than a professional urbanbred folk dance ensemble member, yet the dances constitute a different level of existence. Each researcher may place these dance activities on a different level. This essay sets out a model which may be utilized as a basis for such decisions.

Dance Research Journal 31/1 (Spring 1999) 


\section{Past Studies}

For purposes of this essay, two studies, the first by Joann Kealiinohomoku and a later study by Andriy Nahachewsky, have raised important questions for creating analytical categories for the study of folk and traditional dance, both theatrical and in the field. Both authors have pointed out that Felix Hoerburger (1968) used the terms "folk dance in its first existence" to distinguish dance in the field or in its "original" existence from "folk dance in its second existence," which covered what he termed "revival" dancing. These categories were appropriated by Joann Kealiinohomoku (1972) in a seminal article that raised a number of important questions to sort out "folk dance" as a concept and a field of study. She utilized Hoerburger's terms to characterize the differences between "first existence," indicating folk dances in what I term the field, and "second existence," meaning (among other phenomena such as theatricalized performances) the massive recreational folk dance movement that involved well over a million participants in the United States in the period from 1950-1975 (7). Kealiinohomoku's article addressed one of the most crucial differences between "first existence" and "second existence" dancing: the manner of transmission. In "first existence" dance environments, those individuals who grow up in a society in which dancing constitutes part of the living tradition of their lives learn dances primarily in a one-on-one situation similar to the way in which games and language are acquired, that is generally, but not always, in informal situations in a trial-and-error fashion. Such a situation, therefore, constitutes a branch of folklore studies. The dance repertoire which such individuals acquired usually consisted of a body of choreographic and movement material that was in vogue at the time and in the movement styles specific to the region in which they lived, or by immigrant groups learning from older generations.

By contrast, the typical professional folk dancer in a state dance company is, with some exceptions, an urban-born individual who has learned her or his repertoire in much the same way as the folk dance hobbyist from the United States, Japan, or the Netherlands, rather than from an individual from "the field" in his own district of the same nation-state (8). These professional dancers learn their repertoire from a teacher in a conscious fashion in studio/ classroom environments. Their "native" form, if they have one, is often classical ballet or some form of social dance (9). The professional dancer from the state ensemble acquires a wide variety of styles and forms so that even if a specific dancer comes from the field, he or she acquires all of the other styles featured in the company repertoire in the same manner as do urban-born colleagues.

Kealiinohomoku characterized the state folk dance ensembles as:

a government-sponsored organization of gifted dancers under the direction of a well-known choreographer. The latter coordinates and theatricalizes first existence dance into slick and attractive show pieces, in order to present a variety of forms that represent different regions of the country. $(1972,392)$

In many cases, the first existence dances are not even referred to by the choreographer. For example, Igor Moiseyev's Bulba purportedly from Belorus, is in fact, as indicated by one of his biographers, an original choreography created without reference to any specific dance in the field (Chudnovskii 1959). Moiseyev made clear that he was "against the literal transplantation of the folk dance to the state... and that there are some character dances... [which] have become an improved version of the folk dances from which they stem" (Chudnovskii $1959,28)$.

In another approach to this topic, dance scholar Andriy Nahachewsky (1995) proposed 
"presentational" and "participatory" as categories to distinguish, in a general way, folk dance in presentational and field contexts. He has suggested, however, that rather than considering these as separate categories, they be conceptualized as a continuum: "Some readers may imagine that these categories are distinct in practice, creating a dichotomy or division in dance phenomena. Indeed, this is far from true. These two conceptual categories are idealizations, opposite poles on a theoretical continuum" $(1995,1)$.

I would agree that, when people in the field prepare a performance of a dance for presentation that is native to them as a social dance form, Nahachewsky's concept is useful for analyzing the choreographic differences in such performances (10). In many ways, in some instances such as I am describing for state dance ensembles, semi-professional companies, and amateur performances, the "presentational" and "participatory" categories form two separate genres. For example, the dancers in the state ensembles often do not know the "participatory" dance tradition upon which a specific choreography is based. They are often likely to participate in contemporary urban social and vernacular dances as their "native" tradition and they have often received their basic formal training in classical ballet, which companies such as Moiseyev require.

For purposes of illustration, I propose a visual model of two continua representing the two genres: the field and the stage (see chart). In this model I show how Igor Moiseyev who, as one observer states, "uses some steps based on folk dances" (Mazo 1998, ix) represents the character dance end of the spectrum in contrast to the choreographic output of Lado and the Dora Stratou dancers of Greece, which are deeply committed to the extensive use of authentic elements. Above the line I have placed various professional groups, with those companies that have the least use of authentic elements at the top, while below the line are groups of traditional performers that demonstrate varying degrees of formal choreography and staging techniques common to performing companies. The groups nearest the line utilize the most theatrical elements also common to professional dance companies. Utilizing this model, the researcher may find that a village group whose performance he or she classifies as "in the field" may be placed below the line. By contrast, the investigator may choose to place a specific performance of that same group above the line if their presentations in festivals are theatricalized to any significant degree. In Eastern Europe, some village groups offered arranged selections from other areas in their district, or even the nation-state, sometimes taught to them by a professional dancer. I would classify such performances as above the line. (Numbers following certain groups are from the JVC collection; see video list.)

Any scholar wishing to conduct research in this area may use this or a similar chart for mapping the use and comparison of authentic and theatricalized elements. This list is not exhaustive, but suggestive.

\section{Issues of Representation}

One might inquire: What has dance to do with political and social representation? Some individuals might question the notion that dance is political, and yet I wish to analyze how these state-sponsored folk and traditional dance companies accrued valued symbolic and cultural capital for their respective nation-states. Political representation of power through dance performances does not constitute a new concept. As Herzfeld observes, and I concur: "Visual and musical iconicities have been especially effective in rallying entire populations..." (1997, 27). Giurchescu agrees: "sophisticated performances, staged according to the Soviet model, were meant to symbolize through good technique, beautiful appearances, homogeneity, colorful costumes, and decoration, etc., etc. the achievement of the socialist policy, the happy life 


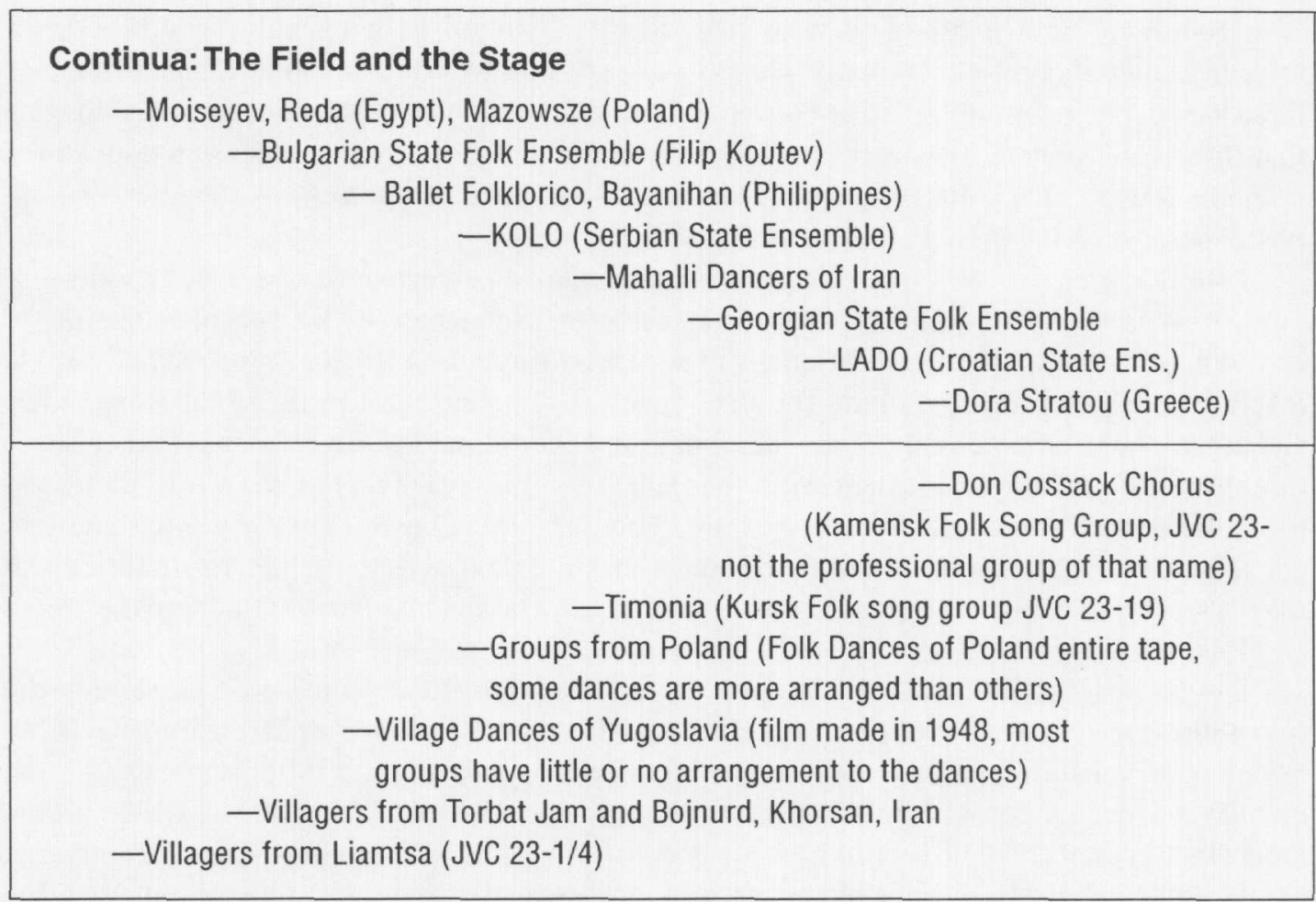

of the youth in the Communist countries, etc." $(1994,17)$.

Thus a major issue concerning these genres is representation. In "the field," no matter how theatricalized the presentational strategies employed by the performers, representation of the village or region in a show of local pride or to attract tourists often forms a common goal of public dance presentations in venues outside of the normative social and ritual contexts and occasions of dance performance. Political issues, sometimes unseen in a government-sponsored festival context, for example, may also be taken into account for analyzing multiple facets of representation. Turkish dance scholar Arzu Ozturkmen points out, "the idea of folklore provided the emerging nation-states, and their devoted intelligentsia in particular, with ample opportunities to mobilize their subject populations toward the construction of a national identity" $(1994,83)$.

By contrast, the state folk ensemble purports, as Kealiinohomoku indicated above, to represent the entire nation-state. Of necessity the professional dancers, singers, and musicians must therefore perform a wide variety of dances and music outside of the tradition in which they were reared. Furthermore, the vast majority of performers found in professional folk dance companies come from urban environments, often the capital city, and have no previous contact with field traditions. They learn their art in a formal classroom setting. In addition, members of the state folk ensemble are generally paid as individuals to perform traditional dances. Members of groups from the field who perform in presentational settings generally, but not always, perform for the benefit of the represented group rather than for individual gain.

The effect of creating powerful emotional responses does not simply occur in the home country, but also resonates with diaspora populations. The response of the Mexican-American population of the United States to the Ballet Folklorico in the 1960s was electrifying and politically transforming of its self-image, spawning dozens of folklórico companies and the formation 
of school programs from grade school to university to teach Mexican folk dance throughout the Southwest and California. This response alone deserves a full-length study (11).

Historically, the Baroque court of Louis XIV consciously adopted dance performances crowned by the potent image of Louis XIV himself dancing the role of Apollo, the Sun God, to create a political message of power (12). Safavid period miniatures from sixteenth-century Iran regularly used dance scenes to illustrate the court in relaxed splendor and might. Nazi Germany mobilized the spectacle of thousands of folk dancers in vast stadiums, valorizing the Volk, who in turn embodied the German state. The U.S.S.R. utilized the technical prowess of dancers and athletes, as well as mass performances of folk dance with thousands of participants, to suggest the power of a state capable of producing powerful world-famous performers and the support of its varied ethnic masses. Of this latter folklore, Russian ethnomusicologists Izaly Zemtsovsky and Alma Kunanbaeva commented: "The 'amateur artistic activity' that the regime so prominently supported consisted, for the most part, of an imagined folklore, one fabricated by socialism for its own purposes. There scholars and frightened performers produced folklore on command, sometimes under the threat of immediate physical violence" $(1997,6)$.

The value of utilizing folk dance for the representation of an entire nation emerges from the common public view that these dances originate in some primordial source of the nation's purest values and that folk dances, music and costumes are timeless and date from some prehistoric period. "Nationalists had produced, among other things, a more effectively aestheticized politics, a politics which could often appear as prepolitical or apolitical precisely in its aesthetic forms - national mythology and folklore, poetry and plays, folk music and grand symphonies, the very identification with the national language" (Calhoun 1995, 232). Thus, the very choice of traditional dance, arguably the most visually spectacular form of performance expression, showing an innocent youth engaged in wholesome folk activity, actually achieves the highly political choice of depicting and representing the nation, in its essentialist entirety, in this "non-political," "innocent" cultural fashion.

Like many non-verbal forms of performance, dance is polysemic, that is, filled with multiple meanings, and for this reason, as popular culture scholar Dominic Strinati reminds us, its meaning is "open to a number of different interpretations" (1995, 208). Traditional dance forms a unique lens through which one may enter a world of embodied representation. Dance performances often create and perpetuate devastatingly accurate portraits of national prejudices, class strife, and ethnic and religious tensions and they express a reality often avoided in the verbal discourse of strident nationalism and chauvinism (13). Political verities can be choreographed and packaged for foreign and domestic consumption, and thus the state folk dance ensemble often claims to represent the "true and authentic" national spirit in the most essentialistic fashion. Thus their performances merit a closer reading which penetrates beyond the spectacle, the footlights, the choreographic athleticism, and the striking costumes. "Culture producers consciously or unconsciously (usually the latter) instill meanings into cultural products which are then decoded or interpreted by audiences in relatively diverse and independent ways which are none the less, in the final analysis, in keeping with some general dominant ideology" (Strinati 1995, 127). This study searches for ways to analyze the multiple meanings in the decoding and deconstruction of those colorful performances.

\section{Representation Issues of State Dance Ensembles}

The claim of representation of an entire nation/state by state folk ensembles invites the question of who is to be represented, and, perhaps more importantly, who is not to be represented 
in the repertoire. This, in turn, brings up the issue of how specific ethnic groups are to be choreographically represented. Professional and semi-professional national state companies, and some amateur folk dance companies, their repertoires, and the ways in which they are characterized in movement and in print, raise important issues of representation on a wide variety of levels-political, historical, ethnic, economic, gender, and aesthetic-among others. State ensembles constitute the highly visible intersection of ethnic and nationalist representation and interests by valorizing folklorized and idealized visions of village and tribal societies filtered through the national capital city and the elite populations residing there. The fact that the various professional dance ensembles feel the need to make claims of authenticity and connections to dance in the field establishes an important element of the professional state folk ensemble's image.

On a recent visit by Ballet Folklorico de Bellas Artes, a national company of Mexico, the representation of the state of Chiapas by a group of waltzing women lilting lightly about the stage in lacy black dresses gave no hint of the harsh reality of insurrection in that unhappy region, witnessed by $\mathrm{CNN}$ and the daily newspapers, in which soldiers chase peasants through the streets, break down their doors, and kill any person suspected of resistance. The official Ballet Folklorico program notes underscored my impression of unreality: "Chiapas. A land of fantasy where we dream of places that grow in tropical jungles; places where the dwellers are happy people who abound in musical inspiration and develop beautiful folk dances... Their costumes are inspired by the tropical flowers, and they reflect the golden sands of the coast, and the majesty of the wooded mountains" (Ballet Folklorico de Mexico Program notes 1995, n. p.).

On the other hand, in the repertoire of Lado, the Croatian Ensemble, in a concert marking their fortieth anniversary, the 1989 premiere of $\mathrm{Na}$ Baniji bubanj bije, a suite of dances from Banija, choreographed by Dr. Ivan Ivancan, was included. It depicted the lives and differences between Serbs and Croats in the villages of this region, which was to be engulfed by war between them within two years, and it presaged the deep tensions and differences between these two ethnic groups through a highly effective choreography.

To date, no scholarly inquiry, using anthropological theoretical and methodological approaches, has been conducted concerning the establishment, maintenance, and representations of these large-scale dance companies. With the collapse of the former U.S.S.R., some of these companies are beginning to wane or metamorphose. With the historical perspective of the past fifty years, we have now reached a point to assess the impact of these companies and the various messages that they conveyed, and to some degree, still convey. In the post-Cold War era, what will be the role of such ensembles? How has their representation changed in the light of new ethnic, nationalistic and political realities (14)? These are questions to challenge dance researchers in this field.

For fifty years, the makings and portrayals of all of these events, and many others, were cast into relief or, alternatively, masked by similar choreographies from dozens of dance companies, their dancers wearing colorful quaint costumes and sporting friendly smiles. These companies almost all claim to be ambassadors of peace and friendship. "And finally, more than being ambassadors of goodwill, Bayanihan dancers have brought joy into the hearts of millions in a world and age wracked by conflict and anxiety" (Bayanihan 1987, 94). For the past fifty years, these state-sponsored professional folk dance companies have dominated concert stages around the world. In many ways, the end of the Cold War brought to an end what I call the "golden era" of these companies and the present period, at the end of the twentieth century, seems an appropriate time to analyze their role and the meaning of their performances

Dance Research Journal 31/I (Spring 1999) 
in the political propaganda strategies that characterized that period.

\section{The Ensemble of Folk Dances of the Peoples of the Soviet Union: The Moiseyev Dance Company}

In the 1950s, the impact of the one hundred Moiseyev dancers, performing never-before-seen, synchronized choreographic feats with the power and ease of circus acrobats created an electrifying impact on audiences worldwide that is difficult to imagine for those either not present or unaware of this phenomenon when Moiseyev first burst upon the world. Concert halls around the world and in the United States echoed to the enthusiastic applause of huge audiences that flocked to see the first dance from behind the Iron Curtain.

In many ways, the Moiseyev company harks back as much to the choreographic past as to contemporary folk dance. Igor Moiseyev, a formally trained ballet dancer, utilizes a vocabulary of movements that derives from character dances of nineteenth-century classical ballet. His choreographic devices and strategies are not concerned with authenticity, but with spectacle and a particular kind of national representation. He wishes to understand the core psychological character of each nationality that he choreographically represents in his repertoire, and then to create a dance or a suite of dances that represents that national trait.

Upon closer analysis, it becomes clear that the Moiseyev Dance Company (A Gala Evening, videotape, 1987), utilizes character dance and ballet-based techniques as its primary source of movement practice. A close comparison with the entries for Russia in the dance examples found in the JVC collections (tape \#23) demonstrates that the Moiseyev Company falls in the totally presentational area of the continuum that I used as a model, and the Russian dances in the Moiseyev repertoire clearly form a separate genre of dance from the dance performed in the field.

In the late 1940s and throughout the 1950s (and later in countries like Turkey, Iran and Egypt), the world saw the birth, growth, and development of the professional state folk dance ensemble in many countries around the world. The first wave of these companies began after the Second World War. All of the nation-states of Eastern Europe and several regional areas as well had state-sponsored companies performing by the early 1950s. The second wave of companies began in other areas of the world such as the Philippines and Mexico in the 1950s. A third wave of companies, such as those of Turkey and Iran, began in the 1960s and 1970s. In the 1960s, many individuals (I was among them) in the United States and Western Europe founded private companies in emulation of the spectacle and success of these extremely popular dance ensembles.

\section{Representation of People}

Representation manifests itself in many ways in state dance company performances, the two major vehicles being visual and textual. I will peel away several layers of representation as manifest in choreography, costuming, and other elements of production, as well as providing a close reading of the company biographies, histories, mission statements, program notes, and publicity releases that each company provides. Representation on many levels, aesthetic and political, casts an allure for many groups of people in a nation-state. It indicates, among other things, inclusion, participation and belonging. In the United States, formerly all-white advertisements have given way to ethnic inclusiveness. This change from the middle years of the twentieth century to the present, in which white models now share beer, cigarettes, headache remedies, laxatives, and fashionable dresses with people of color, has come about not through altruism or high moral ideals but, rather, because it is good business.

Dance Research Journal 31/1 (Spring 1999) 37 
Cultural theorist Peggy Phelan observes that: "It is assumed that disenfranchised communities who see their members within the representational field will feel greater pride in being part of such a community and those who are not in such community will increase their understanding of the diversity and strength of such communities" (Phelan,1993, 7; Phelan's emphasis). The allure of representation and inclusion is certainly reinforced by reports of groups seeking inclusion in the repertoires of these companies (15). Having one's own dance company to represent each recognized ethnic unit became a political goal, a symbol of recognition, in the former Soviet Union. Mary Grace Swift gives an account of how the Don Cossacks, who had been at loggerheads with the Soviet government since the aftermath of the 1917 Revolution, as a mark of recognition and inclusion were allowed to wear their native clothing and "given official sanction to form their own song and dance groups" $(1968,105-106)$.

Phelan makes an observation that is particularly relevant to this study: "While there is a deeply ethical appeal in the desire for a more inclusive representational landscape and certainly underrepresented communities can be empowered by an enhanced visibility, the terms of this visibility often enervate the putative power of these identities" $(1993,7)$. This point, well illustrated by the choreographies of the people of Chiapas in the repertoire of Ballet Folklorico and the Gypsies of North Serbia in the Kolo Ensemble's programs, demonstrates the inherent dangers of how a specific ethnic group or social unit is represented. Phelan emphasizes this latter point: "Gaining visibility for the politically underrepresented without scrutinizing the power of who is required to display what to whom is an impoverished political agenda" $(1993,26)$. As Phelan wryly reminds us about the illusory chimera of power inherent in visual representation: "If representational visibility equals power, then almost-naked young white women should be running Western culture" $(1993,10)$.

Other areas of representation, subordinate to the main question of national and ethnic depiction, must also be addressed. Issues and strategies of the representation or masking of gender and sexuality immediately arise in the embodied manifestation of dance, an art form exuding sensuality and appealing to the senses. (Thus, dance is more often banned than any other form of aesthetic expression. For example, the performance of dance was banned by governments in Afghanistan and Iran after 1979. The government of Saudi Arabia does not permit women to dance in public.) For the careful observer of the Moiseyev Dance Company, the most striking aspect of the dancers, once their extraordinary technical and athletic skills are absorbed, is the utter lack of sensuality or sexuality they display. The interaction between the sexes resembles a primary grade school yard in the characterizations of boys and girls, bashful in each other's company. In the written description of one of his choreographies, Moiseyev states that: "The whole number is composed of such choreographic dialogue of joyful "quarrels"' (Cheremetievskaia n. d., 7). The dancers all portray one-dimensional and interchangeable individuals, forever smiling and happy, who seem to be so doll-like as to have no bodily functions.

The contrast with the Ballet Folklorico in this respect is striking. In the dances of Vera Cruz, Huasteca, and the wedding scene from Tehuantepec, a subtle but powerful sensuality, through the movements and attitudes of the performers, heightened by effective lighting, pervades these choreographies. In the latter suite the dancers mimic the mating of turtles with unmistakable sexual references as does the groom carrying off the bride prior to the wedding night. Similarly, a raw and powerful masculinity informs Amalia Hernandez's choreography (much copied by other groups) of the Deer Dance of the Yaqui Indians. Such sensuality is totally absent from the productions of the Moiseyev Company.

Of all the Soviet ensembles I have viewed, only the Georgian national company brings a 
display of adult, powerful male sexuality to its performances. Female sexuality in the same ensemble is very muted, which accurately reflects the relationship between males and females in that society. The dichotomy between male and female gender representation, which every audience member I have spoken with has noted, is further evident in that the company has fifty male dancers and eighteen females, and the spectacular and varied choreographic roles of the male dancers stand in stark contrast to the essentially monochromatic female choreographic duties.

Female sensuality, experienced in the Ballet Folklorico and some Western African companies such as those of the Ivory Coast and Senegal, are absent from Moiseyev. Bakhor, the Uzbek State Company, utilizes a highly understated sexuality that does not reflect the traditional Middle Eastern and Central Asian image of the dancer as a paid sex worker. Surprisingly, the Reda company of Egypt attempts to mask the very overt sensuality for which Egyptian dance is famous (16). While the peasant frolics of Bayanihan exhibit a Moiseyev lack of sensuality, the Muslim dances of the southern Philippines and some of the tribal dances of the north display and celebrate female sensuality. But in the politics of representation, the Muslims of the Philippine southern islands constitute the "Other," while the idyllic frolics of the Tagalog-speaking peasants, representing the "true" Philippine character, exhibit a display of adolescent coyness and innocence.

Representation of class also forms an issue in several of the state-sponsored ensembles. In the Spanish Colonial Suite, Bayanihan represents the urban elite in a positive light through sumptuous dance productions. The elite display stunning costumes and elegant dance styles, wistfully recalling a more tempered and golden time. By contrast, the few depictions of the upper class in the Ballet Folklorico's Revolutionary Suite portrays them in a feckless, negative fashion disporting themselves in a ballroom, ignoring life around them, while the dance valorizes the heroic working peasant women who rudely burst in upon the ball and drive them away. Moiseyev pokes fun at the pre-Revolutionary petite bourgeoisie in his City Quadrilles, while his staging of an Argentine tango forms an outright satire of the decadent upper classes of the West.

\section{The Nation-State}

First and foremost, a national dance company attempts to embody a nation. This mission is the basic reason for the formation of these companies, and each, in its own way, states this in its program notes and other publications. They also attempt to find strategies to visually depict all of "The People" of the nation-state: the Ukrainian State Ensemble, under the direction of Pavel Virsky, visually represented the entire Ukrainian nation through an opening choreographed spectacle in which all of the dancers appeared in the major costume types, representing villages and regions from all over the Ukraine. The dancers paraded impressively around the stage and, in a final gesture, symbolically presented bread and salt, the Slavic ritual of welcome and greeting, to the audience.

In the past few years, social scientists have begun theorizing the phenomenon of the nation-state on a number of levels, questioning its existence and the popular acceptance of the nation-state by the majority of the world's population as a given in their lives. Because the nation-state has formed the dominant political unit over the past century, scholars are beginning to question the "naturalness" of the nation-state as an entity. Sociologist Craig Calhoun remarks: "One of the ironies of modern social theory is that the "natural' has come to seem the realm of the stable and immutable, that which humans must accept as given" $(1995,283)$. This reification of the nation-state and other such concepts has had serious implications for

$$
\text { Dance Research Journal } 31 / 1 \text { (Spring 1999) }
$$


any study such as this one. Calhoun continues:

This construction of "cultures," "societies," and "nations" as basic units of modern collective identity and of comparative social science research has significant implications. In the first place, it implies that each one is somehow discrete and subsists as an entity unto itself rather than only as a part of a world system or some other broader social organization or discourse that defines it as a constituent unit or part. This boundedness is suggested, in large part, by the sharp boundedness of modern states; the ideology of nationalism promotes the notion that each has its own singular culture (and vice versa). $(1995,53-54)$

In their representation of their respective nation-states, national dance companies visually epitomize and embody Benedict Anderson's famous study, Imagined Communities (1991), in the essentialist manner of their choreographic portrayals, as the example of the Ukrainian State Ensemble's opening demonstrates. Anderson's potent image is of individuals tied together through imagining themselves rising together and reading the newspaper over coffee, which has replaced actual personal relationships, because, in the nation-state, one no longer has face-to-face contact with all, or even most, of one's countrymen. One must therefore imagine a similarity between oneself and one's largely personally unknown fellow citizens to establish a coherent society. The performances of state-sponsored dance ensembles putatively represent "all of the people" of the nation-state; however such performances do not represent all of the people. Rather, choices are made. Some of those choices stem from deeply held philosophical stances concerning which people represent the nation "properly." For example, a common choice for representing the "pure, noble" soul of the people through folk dances, music, and costumes is most often the peasant, a tribal group, or some other rural inhabitant.

As Herzfeld observes: "Nationalism is directly predicated on resemblance, whether biogenetic or cultural. The pivotal idea is that all citizens are, in some unarguable sense, all alike..." $(1997,27)$. The dance companies representing multiethnic, multicultural entities such as the former U.S.S.R., Yugoslavia, Iran, Mexico, and the Philippines have been designed to demonstrate the essential equality of all of its rainbow of citizens. Dozens, even hundreds, of dancers-young, slender, energetic in traditional garb-represent millions of people. So powerful is the concept of the unity of the nation that it can sometimes be reduced and essentialized to a single individual, as in the embodiment and representation of the collective nation about which the 1969-70 souvenir program for Ballet Folklorico de Mexico enthused: "And in her art, audiences around the world see the Mexico she [Amalia Hernandez, founder and artistic director] cherishes, the Mexico she celebrates in opulent theatrical terms, the Mexico she is" (Ballet Folklorico de Mexico 1969-70, n.p.; emphasis mine).

Many people accept the unrealistic claims of authentic representation of the national treasure of folklore through a dance performance: They imagine themselves as looking like and being those representational images. But as Strinati sagely observes: "Reality is always constructed, and made intelligible to human understanding by culturally specific systems of meaning. This meaning is never "innocent," but has some particular purpose or interest lying behind it, which semiology can uncover" (1995, 110).

Thus essentialism, epitomized by the presentations of these dance companies, becomes a strategy of representation of the state and "The People." Anthropologist Michael Herzfeld observes that: “...Essentialism is always the one thing it claims not to be: it is a strategy, 
born... of social and historical contingency. The agents of powerful state entities and the humblest of local social actors engage in the strategy of essentialism to an equal degree" (1997, 31). On the issue of representing the vast former U.S.S.R. with its hundreds of millions of population, Igor Moiseyev claimed to build a "repertoire so broad that it would truly reveal the national character" (Libman 1986-1987, 21). Thus, one hundred dancers may reveal "Soviet Man" through the colorful medium of "folk" dance. Igor Moiseyev holds the opinion that he can find the single essence of any specific group for use in portraying them in dance. "A people who are known for a fervent life of combat shows this fervor for fighting in their dances" (Cheremetievskaya n.d., 31). In this manner an entire group of people can be reduced to one character trait: combativeness.

In contrast to these essentialist portrayals of the nation-state, dance companies also demonstrate the political and ethnic tensions inherent in the multicultural, multiethnic, multilingual states that characterized many of the contemporary states like the former Soviet Union and the former Yugoslavia. While the professional state ensemble embodies essentialism as it employs choreographic strategies to highlight that all Greeks, Iranians or Mexicans are the same, their programs must also show, and even celebrate, a rainbow ethnic diversity. This need to represent choreographically the diversity of the several ethnic groups in the respective nation-states creates a source of tension which anthropologists Urban and Sherzer identified as the tension between "assimilation and differentiation" (1991). They point out contrasting methods that various nation-states in Latin America utilized for dealing with indigenous peoples: "assimilation" implies attempts at erasing local identity and culture while "differentiation" suggests the highlighting of cultural differences. Such tensions, which the former Soviet Union attempted to balance by allowing dangerous feelings of nationalism to find outlets through seemingly innocent activities such as wearing national costumes and folk dancing, ultimately destroyed the state. In spite of inclusion and representation, at least through the highly visible national dance companies and other folk-oriented performances which displayed "the people" en masse that were heavily supported by the national governments of the former Soviet Union and Yugoslavia, these same nation-states collapsed. The failure of these states is semiotically reflected in the various readings the public received from these dance companies. Their respective former governments "feared variant cultural readings-minority self-determination, youth nonconformism, cultural dissidence-that might undermine the universalist claims" (Herzfeld 1997, 27-28). The Bulgarian State Ensemble of Folk Songs and Dances never included Turkish dances in spite of the fact that Turks constituted over a tenth of the population. Politicians often undervalue, disparage and underestimate the power of art, which seems an innocent and innocuous vehicle through which the politically powerless, especially ethnic and minority groups of various types, may be allowed visual representation. These politicians fostered the illusion that such representation could be equated with political and social participation in the nation-state. After 1948, when Russian political dominion had been reestablished in the Baltic states of the former U.S.S.R., and in order to show a return to normalcy which included the domination of the Russians in the area, "Massive song and folk dance festivals began to be held, which included an increasing number of Russian songs and dances as well as those of other republics" (Misiunas and Taagepera 1993, 115). The former Soviet government made the important and telling point, through these dance companies, that they respected and protected the primordial traditions of their many peoples, unlike the West, which the Soviets claimed had as an aim the eradication of the arts of the colonized peoples they politically dominated. This point of view resonated in countries like Egypt, Mexico, and the Philippines. 
International world fairs and visits by heads of state are often accompanied by state dance companies, with their heady mix of athletic and handsome youth, which sends the subliminal message that "we are a nice, innocent, welcoming people and our country is a nice place to visit." The visit of Anwar Sadat, former president of Egypt, was accompanied by the Reda company, the state dance company of Egypt, which danced in the rotunda of the Los Angeles City Hall before the mayor and city officials. The slim, undeniably beautiful young Egyptian women, balancing candelabras on their heads, charmed their hosts, who watched the performance with rapt attention.

Thus, one of the most important questions is: Who is represented in the repertoire of each of these dance companies? Once posed, this question begs, as Phelan suggested, two others: Who is not represented and why? And how are they represented?

\section{Who is Represented?}

One of the first questions to be raised in the formation of a repertoire for a folk dance company is: Who are the folk? This is not an easy question, but one which requires that choices be made. The answer to this question differs from company to company, and is frequently determined by a basic philosophical issue posed by the artistic directors. For example, for Professor Zvonko Ljevakovic, founding artistic director of Lado, the folk were clearly rural peasants. People from towns and cities were not, by his definition, "folk," and thus, their choreographic expression did not merit inclusion in the repertoire showing the "pure" Croatian national spirit. This position clearly reflected folklore scholarship and intellectual attitudes of Eastern European anthropologists and folklorists of the early part of the twentieth century, and consequently, as a member of that (exclusively urban) intellectual milieu, the repertoire he created for Lado reflected this attitude. The dance and song repertoire of the Croatian state ensemble almost exclusively represented regional rural expression. The repertoire of Lado has only recently added urban dances from Split, but to this day, it still remains largely a repertoire representative of the peasantry.

The Moiseyev company also largely represents and celebrates peasant culture, valued for its work ethic and simple moral values, celebrated in dance by Igor Moiseyev, who observed:

Folk art, whatever its form, is always on the side of good, always wholesome and optimistic. In folk-lore[sic] we find the vices denounced and held up to ridicule while praises are sung to man's better instincts... Folk art, the art of the people, is a splendid means of educating the masses, for it can speak their own language, simple, colorful, and replete with wisdom. (Chudnovski 1959, 23)

[Moiseyev wanted] not only to bring out the national features but common human traits possessed by all people: these are a joy of living, industry, a love of gaiety and a sense of humour, and a wholesome morality. (Chudnovski $1959,32)$

However, the contrast between Lado and Moiseyev forms a vast aesthetic and philosophical chasm in how their respective rural populations are represented and this, in turn, is reflected in the attitudes of the artistic directors toward issues of authenticity, a topic to which I will return often in the course of this study.

By contrast, the repertoire of the Bakhor, the State Ensemble of Uzbekistan, primarily consists of dances created from the urban solo improvised dance genre formerly performed 
by young male professional dancers as well as women in their own private quarters (see Shay 1997). Nothing approaching authentic rural regional dance appears in their repertoire. Between these two examples, one finds Bayanihan of the Philippines and the former Mahalli dancers, both of which have a mixed repertoire of regional peasant, indigenous tribal, and urban dance genres represented in their repertoires.

\section{Authenticity}

Once the issue of who is to be represented is decided, the next issue that arises is how they are to be represented. Igor Moiseyev had no interest in authenticity and declared this himself; he did not use authentic folk movements any more than nineteenth-century classical composers used authentic folk melodies. Rather, he utilized character dance, that form of classical ballet used in many nineteenth-century ballets to depict the so-called "national variations" familiar to any viewer of ballets from that period, in which "Hungarian," "Polish," and/or "Spanish" dance variations appear. He greatly expanded and developed character dance to produce a folklorized dance style that was initially unique to the Moiseyev Dance Company, and subsequently many other companies, both inside and outside of the former Soviet Union, faithfully emulated it.

By contrast, Zvonko Ljevakovic, former artistic director of Lado, meticulously relied exclusively on authentic movements, costumes, and other elements to create his choreographies. He made the conscious choice to eschew the use of alien, non-authentic elements (i.e., classical ballet, modern dance and other forms of Western theatre dance) in his choreographies ( personal interview, September 28, 1967). He conducted original research and spent much time in the field learning the materials that he staged through witnessing and practicing the dances and music that were demonstrated for him by his many peasant informants.

Amalia Hernandez, artistic director of Ballet Folklorico, stands somewhere between Moiseyev and Ljevakovic, but closer to the former. She has unabashedly stated that those who wish to view the truly authentic should go to the village in question and wait for several months until that dance is performed. "Authentic? You want authentic? For that you would have to go to the smallest village of my country at a certain hour on one certain day of the year. There, outdoors, in the shadow of the church, you would have a true folkloric experience. You might have to wait six months in that village before it happened, but it would be authentic." Clearly, regarding the degree of authentic elements she uses in her creative works, Hernandez makes choices, for she adds: "There is no way to move village dancers directly onto a professional stage. Everything must be adapted for modern eyes — costumes, lighting, steps, espectáculo. Without stagecraft and adaptation for size and perspective, the originals look like nothing" (Carriaga 1969, F1). Nevertheless, her program notes claim hours of research time expended in gathering dances in the field and studying historical sources for her pre-Columbian choreographic works, which, when viewed, arguably owe as much to Martha Graham techniques as they do to Aztec codices. Hernandez stated: "What we make are theater pieces based on folklore. We research carefully, and costumes are created in the particular style appropriate for the large stages where we perform" (Carriaga 1969, F1).

Underscoring the need to claim authenticity, Bayanihan spokespeople state: "Take it from the people' became the PWU [Philippine Women's University, the home of Bayanihan] researchers' guiding philosophy, one which fired them through forbidding terrain, inhospitable weather and austere living conditions. The desire for authenticity in choreography, music and costumes for the dance repertoire that the PWU set out to develop saw a team composed of Kaslig, Urtula and Isabel Santos, a literature professor who would later become 
Bayanihan's costume director, touring the length and breadth of the country in succeeding years" (Bayanihan 1987, 83).

Issues of authenticity are raised in relation to all folk dance companies because of the idea that one is presenting an "authentic" representation of the nation by using its purest, most primordial materials: folk art. The artistic directors and choreographers of most dance companies who perform traditional dances spend a great deal of time conducting research or, conversely, at least attempting to justify and show their works to be "authentic."

The questions I raise do not concern the amount of research undertaken, but rather to what degree an individual choreographer or artistic director commits himself or herself to the use of authentic elements in the work. The result of this commitment translates into the degree of authenticity found in the resulting choreographies and performances. There is no question that each choreographer has a right to some degree of artistic license. The quest of this study is to ascertain the degree to which the artist claims to cloak himself or herself in the sacred robes of authenticity and the degree to which authenticity is actually utilized.

\section{Anatomy of a Dance Company}

In the following section, I address the technical limitations of dance companies in general: financing, the selection of a repertoire and the ways in which choreographies are structured to achieve visual representation, methods of research employed by the artistic directors, the hiring and training of artists, the acquisition of a costume collection, the music, sets, and other technical problems encountered by all folk dance companies, state-sponsored or private. This discussion will give the reader some understanding of the technical underpinnings of these organizations and further the understanding of how each of the individual ensembles operates and to what degree technical issues influence choices of repertoire.

For purposes of a fuller understanding of how folk dance companies, both state and private, project, consciously and unconsciously, the specific images which they convey to their viewers, one must take a look behind the curtains to understand how folk dance companies operate. Certainly some of the observations will be specific to some companies and not to others, but to mount productions of traditional dance, specific ingredients are required which have a particular bearing on the final product and are crucial in creating successes or failures. These elements include financing, the selection and development of repertoire, methods of research to underpin the creation of dances, the selection and training of artists, costume acquisition and production, creation and use of sets, behind-the-scenes support, administrative and technical, and publicity. Discussion of these elements provides an insight into the limitations which all of these companies, at least to some degree, experience and which bear a role in shaping the final choreographic products that the audience experiences.

The images created from these highly complex ingredients form a very different aesthetic project from classical ballet and modern dance companies which, for the most part, reflect and claim to project the personal images of specific individual choreographic artists such as Martha Graham, George Balanchine, or Mark Morris. In contrast to the "on-the-ground" aspect folk dance claims to reflect, classical ballet and modern dance choreographies are created through a specific individual's aesthetic imagination, often representing that individual artist's emotional states, aesthetic interests, personal life experiences, and philosophical outlook, rather than any attempt at representing a particular group. I certainly do not want to give the impression that these personal and highly individual elements are absent from the creators of traditional and folk choreographies, especially if one reads the dramatic and outspoken interviews of an artist like Amalia Hernandez, whose fierce creativity rings with the same

44 Dance Research Journal 31/I (Spring 1999) 
aesthetic convictions as those of Martha Graham, but rather each of the traditional companies stresses and emphasizes the group: the "people's" art, the pure spirit of the aesthetic expression of a specific ethnic group of people (see Carriaga). The artistic directors of the statesponsored folk ensemble must, to some degree, efface their own contributions, thus creating a tension between the traditional elements and their own individual, highly personal choreographic and aesthetic vision. Nevertheless, like the creations of Martha Graham, Doris Humphrey, or Antony Tudor, the works of these artists are also unique. Make no mistake: had artists other than Igor Moiseyev, Robert De Warren, Mahmoud Reda, Mukharram Turganbaeva, Zvonko Ljevakovic, or Amalia Hernandez created works to represent the former Soviet Union, Iran, Egypt, Uzbekistan, Croatia, or Mexico, the results would have been dramatically different. Even in the most socialistic societies, the representation of the nation through the medium of a state-sponsored folk ensemble is produced through a unique artistic vision, but because the dances purportedly originate with "the people," the characters of the founderartistic directors and choreographers are often more muted, and many individuals among the public largely believe the fiction that the choreographies they view on stage reflect actual dances as they would be experienced in a traditional, field setting.

After a brief discussion of each of these elements, in the respective sections devoted to each individual ensemble, I will describe each ingredient for each company and the impact on their performances and the images they create.

\section{Finances}

Since each of these companies, to some degree, constitutes an official arm of its respective government, some, if not all, funding comes from that source. This, of course, varies widely, and in many ways reflects the economic philosophies and realities of each nation-state. Some of the companies, such as Ballet Folklorico, Moiseyev, and Bayanihan earn important sums of money from touring. In addition, other assets, such as the use of a building, a theatre, offices and other valuable space, are provided by the state or a municipality for rehearsals, administrative offices, and storage of costumes. These funding sources impose restrictions and limitations such as how many performers one may hire or the opulence of sets and costumes that a single choreographer may command at his or her disposal.

Some of the ensembles receive an important portion of their financing through tourist dollars. Almost all visitors to Mexico City are taken to the wonderful Bellas Artes, the old Baroque theatre in downtown Mexico City to see Ballet Folklorico and its world-famous Tiffany curtain. One sees tickets for Ballet Folklorico, one of Mexico City's major tourist attractions, for sale everywhere. This provides the company with a never-ending source of new viewers. For many viewers, the romantic performance presented by Ballet Folklorico embodies and encapsulates the essence of Mexico. Such "authentic" and unforgettable depictions of Mexico will not be sullied by news reports from CNN. So immediate are the images projected by the Ballet Folklorico de Mexico, that they remain forever fixed in the mind of the viewer who feels that he or she has shared an evening of the "true soul of Mexico," as one friend remarked leaving that impressive theatre (November 1974).

Similarly, visitors to Moscow and Tashkent are often taken to see Moiseyev and Bakhor respectively. Other companies, like Lado from Croatia and the Mahalli Dancers of Iran, were not on any regular tourist itinerary; Zagreb and Tehran are not major tourist cities. However, Lado received a major portion of its financing by touring and performing each summer in hotels and theatres along the length of the Dalmatian coast.

Foreign touring constitutes a major element in financing some of these companies.

Dance Research Journal 31/I (Spring 1999) 
Moiseyev, Ballet Folklorico, and Bayanihan, in particular, had major annual tours. The touring schedules of Lado and the Mahalli Dancers were far more modest, while Bakhor's foreign tours were almost totally, with one exception of which I am aware, confined to third-world countries because, until 1989, they had not attained the "Academic" rating which permitted Soviet companies to travel in the West. Outside of the former Soviet Union, little known is the fact that the former U.S.S.R. had a system of ratings which defined the scope of foreign touring. Moiseyev's appellation of "Academic" ensemble (shared with the Kirov and Bolshoi Ballets, Piatnitskii Chorus, and the Georgian State Ensemble, among a few others) permitted them to be engaged for foreign tours in the Western world, thus providing a valuable source of hard currency. The designation of the all-important "Academic" title was always accompanied by great hoopla and an impressive public ceremony in which government representatives officially bestowed the coveted honor. Companies like Bakhor and the Armenian State Dance Company occasionally traveled abroad in the West, but these forays, usually sponsored by special interest groups abroad, such as the Armenian community or the American Society for Friendship with the Soviet Union, were exceptional. By contrast, the former Mahalli Dancers received the bulk of their funding through the Ministry of Fine Arts and the private endowment of the former Empress Farah Pahlavi. Thus, we see a wide range of funding sources which formed the economic underpinnings of these ensembles.

\section{Research Strategies and Methods}

Because the directors and choreographers of these companies make claims of authenticity, the research each conducts, or has access to, allows her or him to determine the most characteristic movements, steps, and poses found in a specific geographic area or among a particular ethnic group. Through the research, however conducted, they can utilize the most "typical," "well-known," or "popular" dances in a specific area.

It is impossible to vouch for the actual amount of time and effort a single individual artistic director expends in research and which methodologies they pursue. The claims of many of them, at least in so far as the results of their efforts are demonstrated in the final product of choreography and staging of their companies, if not exaggerated, are certainly open to interpretation. Such claims are made to bolster assertions of authenticity. All of the state dance companies, including Moiseyev, stress the amount of field work the artistic director has undertaken. Establishing the truth of their claims does not form part of this study, because aside from being generally unverifiable, the claims made are of interest only insofar as they pertain to issues of representation.

The claims for research of these artistic directors are not verifiable, because they have, with one exception, never been published. Dr. Ivan Ivancan, who served as artistic director of Lado for some years and created a number of choreographies for that ensemble as well as for his own highly proficient amateur company, Jozo Vlahovic, is the author of an impressive series of meticulously documented field studies. In these studies, Ivancan describes dances from several regions, in both words and Labanotation, provides musical notation, and indepth descriptions of how, when, where, and by whom each dance is performed, as well as descriptions of his informants. To conduct these studies, Ivancan posed a series of questions which he explored in the course of his research.

An artistic director or choreographer can learn dances by using a number of methods. By far the most satisfying is field work, in which the individual goes to the place in which the dance is natively performed. This method is the most gratifying because seeing the dance in situ, one can obtain other important information concerning the relationship of the dancers to 
other dancers of the same and opposite sex, styles of movement when not dancing, and manipulation of clothing, including skirts, hats, kerchiefs, shawls, etc. during the dance. It is possible to learn in the comfort of one's studio by inviting an informant to show one the steps and movements, and even by interviewing the individual. However, the all-important subsidiary information is generally lacking or second-hand, and details and aspects of this information can be incorporated in a staging, which in turn can bring a sense of verisimilitude to a work that has been removed from the field and brought to a concert stage.

This latter problem, how to translate the field to the stage in a way that retains the most unique and authentic elements, forms the greatest challenge to artistic directors of these groups, and all of them have stated this in interviews, or in program descriptions. Additional methods also exist for research, such as using books, for there are many which provide, with varying success, movements, steps, music, and other aspects of folk dances. Except for Iran, descriptive manuals exist in all of the other areas, although many of them appeared after the founding of these companies. Films taken in the field provide an alternative method to journeying to the field, and governments of many nations of the world maintain ongoing projects to record the entire traditional music and dance corpus of all of the regions of their respective nationstate. Projects such as those begun by Bela Bartok and Janos Kodaly for Hungary, the Jankovic sisters of Serbia, Roza Karimova of Uzbekistan, and Frances Aquino of the Philippines are impressive in their rigor, scope, and detail.

While it is relatively easy to believe that individual artistic directors have spent at least some time in the field, the claims for research for choreographies purporting to be from ancient times form a particularly incredible body of questionable claims. Not all of the companies attempt recreating "ancient" dances, but the Mahalli Dancers of Iran and Ballet Folklorico de Mexico, both representing nations with relatively ancient cultures which form culturally symbolic icons that resonate with their populations, have attempted extensive historical reconstructions of dance (17). Robert De Warren, former artistic director of Mahalli Dancers of Iran, claimed to have laid a series of Persian miniatures side by side to obtain a clear picture of actual movement practices of four hundred years ago (Shay 1997). Other groups have variously claimed to study and utilize the results found in friezes from churches (Branko Krsmanovic, a semi-professional ensemble from Serbia), temple paintings, and Aztec codices (Ballet Folklorico de Mexico). While not, to my knowledge, attempting to recreate ancient dances, Dora Stratou, founder and artistic director of the Greek National Dance Company, does make detailed claims for the ancient origins of contemporary folk dances (see Stratou 1966).

\section{Choreographic Strategies and Methods}

In order to incorporate these varied research strategies and decisions into choreography, a variety of choreographic strategies and methods is used. Probably the most characteristic choreographic structure utilized by most of the dance companies under analysis in this study is the suite. Beginning with Igor Moiseyev, all of the companies, with the exception of Bakhor, the Uzbek State Company, utilize the concept of the suite for representation. In this manner, the choreographer can string together, with artful transitions, a series of simple dances that would be theatrically uninteresting if used alone. Choreographers also use customs such as weddings to frame a series of dances. Virtually every state dance company portrays a wedding, or aspects of it, for all the world loves a wedding!

\section{Artistic Personnel}

In order for each of these companies to operate and perform, the most basic ingredient, after 
the construction of unique and successful choreographies, is the group of artists-dancers, musicians, and, in some cases, singers-who can professionally fulfill the choreographer's images. Sometimes certain physical types of bodies, faces, heights, weights, coloring, etc. are required of dancers who embody "the national type." Philippine dance scholar Patrick Alcedo described how many members of the Philippine public were upset that, in the early days of the establishment of the national company, many of the dancers in Bayanihan had the appearance of the Spanish-looking elite of Manila (personal interview, June 5, 1997).

The technical skill of the artistic personnel can sometimes determine representation. A particular dance or piece of music may be so demanding as to be impossible for a group of dancers to perform as it is performed in the field. For example, the Lado Ensemble attempted, unsuccessfully, to recreate the Moreska from the island and town of Korcula on the Dalmatian coast. The native performers of this dance in the small city of Korcula spend hours of time on the performance of this one sword dance ritual. It is accompanied by a large military band that plays music from Verdi's operas to accompany the event, which takes the better part of a full evening. The cast of dancers is very large as is the band. The ritual also features a lengthy oration in Croatian. The size of the cast, the technical requirement for handling the swords, the hours needed for a successful performance, and the numbers of musicians necessary to achieve the sound all lay outside the technical capacity of most of the dancers of Lado (or almost any other company). Their attempt to recreate this work was not successful, and the choreography did not remain long in the repertoire.

I suspect that, for much the same reason, Ballet Folklorico does not attempt to include the famous performance of the voleadores, the famous "flyers" who suspend themselves by the feet from a high pole and spin through the air. No normal theatre could accommodate the equipment required for such a performance. Professional dancers, who must master a large repertoire of dances from a wide geographical spectrum, simply do not have the hours and training facilities available to also master dances with such demanding technical prowess, and whose performers are often devotees who spend all of their leisure time on this one ritual-like event. The possibility of accidents is enormous. Other examples of special skills are dancers who must walk through fire, such as those who perform, in a trance, the Anestenaria or Nestenarki event found in Greek and Bulgarian Thrace. These rituals present unsurmountable technical problems, but occasionally choreographers attempt to stage them because a particular ritual has international fame. Thus, representation, or lack thereof, sometimes takes on a technical aspect rather than a political or cultural bias.

\section{Music}

The difficult and arduous training and preparation of dancers to learn multiple styles of movement and intricate choreographies almost pales when compared to the complex technical problems of providing musical accompaniment. This is particularly exacerbated in cases in which the artistic director insists upon authentic, live music. Since virtually all of the state ensembles utilize live music in their performances, although there are exceptions, a serious problem in these ensembles concerns decisions regarding music. The complex details in obtaining the most accurate music to be represented in the company repertoire proceeds from the enormous diversity of musical instruments, vocal styles, and other ethnomusicological elements found in all of the nation-states represented in this study. Sometimes wrenching decisions must be made about which music to include and which to exclude in the repertoire, because not even the best-financed dance company can afford all of the musicians and musical instruments needed to provide accurate music - there are simply too many instruments found in the coun- 
tryside for the number of musicians that one can afford to employ.

The various companies investigated have made a variety of decisions. For example, the Moiseyev Company employs a Western symphony orchestra with a few folk instruments, such as balalaikas and various types of accordions, to provide a bit of ethnic flavoring. When these are used, these instruments are often featured on the stage among the dancers, whereas the large concert orchestra of Western instruments that accompanies a Moiseyev concert is seated in a pit. The Serbian State Ensemble, Kolo, features an orchestra of strings, flutes and oboes more suited to arrangements of music by Mozart than to Serbian traditional music; the dancers of this ensemble sing in a cultivated urban style.

The Bulgarian State Ensemble, known as the Philip Koutev Company in the West, made a specific decision to create an orchestra of instruments based on the four most prominent Bulgarian native instruments: the bagpipe ( gajda), the end-blown flute (kaval), the bowed instrument ( $g a d u l k a)$, and a plucked instrument (tambura). In addition, the large drum (tapan) provided the percussion. This decision truly contains implications for issues of representation and essentialism. The pantheon of actual musical instruments utilized in the field by the rural population was extremely varied, but the instruments selected by the artistic staff of the Koutev ensemble were essentially perceived of as "Bulgarian," in contrast to instruments of Western or Middle Eastern origin such as the widely popular accordion and violin, oud and darabuka. Brass bands, zurla (double-reed instruments), and clarinets were often played by Gypsies or had associations with only one region such as Pirin (as the Bulgarian government designated the Macedonian ethnic enclave of the southwest). In addition, these instruments, as well as the oud, a Middle Eastern lute, the kanun, a zither-like instrument, and the darabuka (goblet drum) and daf (frame drum) had Turkish, and thus, negative associations.

The Bulgarian State Ensemble, and the numerous amateur groups following its lead, did not simply use the four instruments in the form in which they were found in villages and traditionally played as solo instruments; they were altered in two ways. In their native state these are non-tempered instruments, that is to say, they do not have the standard tunings found in a piano based on a particular tuning. Thus, in order for these instruments, which had generally not been played together before and certainly not in large orchestras, to play in tune with one another, they had to be specifically constructed to have the same pitch. Another alteration or, perhaps better stated, creation, was to take the gadulka, a bowed instrument held by the neck and played like a cello, but much smaller, and create instruments the size of cellos and basses in order to provide a bass and tenor sound to fill out the treble timbres of the original four instruments. The result is a massive sound never heard in a Bulgarian village. Thus, the artistic staff of the Bulgarian State Ensemble created an entirely new musical entity: a folk orchestra which represented all of Bulgaria.

Vocal music is not utilized in all of the ensembles in this study. For example, Moiseyev does not use vocalists. But, in the Bulgarian state company, the all-female choir had pride of place because Philip Koutev was the founder and overall artistic director, in addition to which he served as vocal director, composer, and arranger for the choir. Here, too, while developing an essential "folk voice," Koutev provided two highly creative moving vocal parts to accompany the melody line, not found in the overwhelming production of Bulgarian folk music. The chorus of forty-four voices sang with a professional unity that is truly unique and truly Bulgarian, but not traditional nor, on close inspection, does it resemble the singing found in the field, although vocal duets containing traditional dissonances are featured like a heady spice in their performances. The musical style created by Philip Koutev remains popular with concert-goers today. There is little attempt to produce the many regional styles that exist in 
Bulgaria, but rather, the chorus produces a "pan-Bulgarian" sound. Compact disks of the choral music begun by Philip Koutev, and live concerts by vocal ensembles utilizing the style he originated, are preeminent in world music circles.

By contrast, Lado, the company which by far attempts the most detailed regional musical styles through its own musicians, uses a wide range of instruments. Croatia is the smallest of the nation-states represented in this study. Nevertheless, the complexity of musical types and instruments representing its various regions is staggering. Ljevakovic decided that he would stretch his musicians as far as he could to have the most authentic sounds possible. He occasionally chose to use recorded music for areas which his musicians could not master. For example, the dances from the regions of the Kvarnero Bay (Istria, Krk, Susak, etc.) are traditionally accompanied by two double reed instruments, sopila (plural sopile), which are constructed by master instrumentalists of the region in exact minor sixths. The playing of these instruments, particularly because the two parts are equally difficult, requires hours of practice. For most of its career, Lado used recordings for these unique sounds because Zvonko Ljevakovic's exacting standards did not permit him to substitute other instruments. I also witnessed two players from the Island of Krk who were employed for exceptional instances when Lado wished to make a particularly important impression through the use of live music.

\section{The Repertoire}

Foremost in the thoughts of those who serve as artistic directors of dance companies, such as Igor Moiseyev or Amalia Hernandez, is the entire repertoire. Based on the decisions made about the types of dances and the groups that they represent, choreographies, costumes, and, sometimes, sets are created to fulfill the mission of the company. Each folk dance company has a mission to represent certain "on-the-ground" realities, however fanciful the results may turn out to be. The mission statement in the Bayanihan company's thirtieth anniversary souvenir book encapsulates typical statements made by almost all folk dance companies, state and private: "Bayanihan...proved two things: that dance could be an effective medium for preserving - and showing off-the nation's rich cultural heritage; two, that a folk dance company could be a persuasive force in promoting the Philippines abroad.... Bayanihan has been cited for many things: awakening a new pride among Filipinos in their cultural heritage; preserving and adding a new dimension to the country's dance tradition; building for the country a rich reserve of international good will" (Bayanihan 1987, 6-7).

\section{Costumes}

In the performance of all folk dance ensembles, costuming is the single most important visual aspect of the performance. The costumes worn by the dancers signal, at least to the knowledgeable, the attitude and philosophy of the artistic director regarding authenticity. Zvonko Ljevakovic declared himself dedicated to finding the most varied, valuable, and authentic costumes (personal interview, 1967). For those who study costume, this constitutes an understandable stance for an individual interested in showing the nuances of folk life. Clothing, and particularly folk clothing, constitutes an entire semiotic system. In rural life, clothing, jewelry, and hairstyles reveal to the knowledgeable the exact social status of an individual: age, marital status, religion, emotional condition.

This insistence on authenticity in the clothing or costumes worn by dancers in Lado and Dora Stratou contrasts with costuming practices in most other state-sponsored companies. Amalia Hernandez stated: "In their original form, folk costumes, exquisite in their handiwork, often do not translate exactly to the stage. Our costumes are handcrafted, too, but for 
large spaces" (Carriaga 1969, F1). The costumes of the Moiseyev Ensemble make no attempt to project more than the sketchiest nod to the original clothes upon which they are based. This choice serves as an excuse for some artistic directors to project more contemporary images to their audiences. Many of them dislike the unchic aspect of actual traditional clothing, because they impede the modern aspects of their choreographies. Certain clothing does not lend itself to rapid turns, for example, a common feature of contemporary folk choreography.

Thus, the details of some costumes are frequently at variance with the original clothes that they purportedly represent. As an overall observation, hemlines, silhouettes, skirt lengths, and hairdos are designed to please modern (mid twentieth-century) tastes and the ubiquitous practice of using three yellow, three green, three red, and three blue costumes (or perhaps other colors) pervades the costuming throughout the repertoire. This latter practice was also utilized by the Mahalli Dancers of Iran, who, like Amalia Hernandez and Igor Moiseyev, had fashionable dress designers redesign the costumes to look larger than life on the stage, as well as to eliminate inconvenient aspects of the original clothing which did not enhance the particular choreography. To what degree costumes should be authentic creates an important topic under the rubric of projected images.

Like the technical difficulties that often limit certain types of representation in the abilities of dancers to perform highly specialized dance traditions, costumes, too, can present difficulties. The funding of the various companies looked at in this study varies widely. For all companies, considerable financial investment is made in even the least expensive costumes. For those companies like Lado or the Greek national company under the direction of Dora Stratou, which insist on a high level of authenticity in their clothing, the cost of certain costumes, for example costumes made with real gold bullion embroidery, can range from exorbitant to prohibitive, placing the representation of certain regions beyond financial possibility.

\section{Conclusions}

Through this brief survey, it becomes clear that the scholar attempting an analysis of the largely undocumented choreographies of some of the world's largest and most important dance companies must undertake an in-depth investigation into issues of authenticity and representation, as well as the many technical, political, and social limitations and restrictions which the various artistic directors and choreographers encounter in their careers. Such areas of enquiry will enliven the discussion of these colorful companies and their political, ethnic, and historical choreographic images and strategies of representation. While I have raised some important issues, other investigators will find new areas requiring analysis in this largely unexplored field of research opportunities.

\section{NOTES}

1. I include in this category several semi-professional ensembles such as Branko Krsmanovic of Serbia, Jozo Vlahovic of Croatia, and Koca Racin of Macedonia, which received heavy state subsidies and toured internationally on a regular basis. By state or nationstate, which I use interchangeably, I mean the conventional usage provided by Anderson (1991). In fact, few of the political groupings known as nations have only one nationality, and states like the former Yugoslavia, Czechoslovakia, and U.S.S.R. housed many ethnic and national groups. In their attempts to create a nation-state of these diverse, often unwilling populations, usually utilizing military force, the politicians created unbearable tensions which ultimately destroyed these politcal entities.

2. In many ways, I admire many of the choreographies and stagings of several of these companies, and thus, while I serve in this study as an analytic observer, I am not a hostile witness to their performances. In the beginning, like many audience members, I was swept up by the impact of the considerable spectacle they

Dance Research Journal $31 / 1 \quad$ (Spring 1999) 
presented as well as the considerable, sometimes brilliant, artistry of some of the artistic director/ choreographers such as Zvonko Ljevakovic, the founding artistic director of the Croatian State Folk Ensemble, Lado. I wanted to participate in and create this dance form as a way of life and I wished to capture the positive essence of some of these companies in my own work. But ultimately I realized that these companies embodied policies and strategies of representation, consciously and unconsciously, that mirrored the ethnic, religious, class, and gender politics, nationalism, irredentism and chauvinism of the elites of their respective states, and sometimes specifically those of the majority of the population that they claimed to represent. It is some of those strategies of representation that this study intends to describe and analyze.

3. As a college student in the 1950 s, I belonged to a folk dance group that often used a 1937 film, The Nation Dances, of the Moiseyev Dancers, which the Soviet consulate in San Francisco lent to us. We performed several dances from this film, including Bulba, and we carefully learned each movement accurately, for to us this was the authentic source. Moiseyev dances are still looked upon as authentic by some immigrant Russian groups and a group in San Francisco performs dances that come from that genre

4. This situation is beginning to change. With the collapse of the former U.S.S.R. and the reformation of Eastern Europe, scholars from the region are producing articles in Eastern European languages on what Rumanian scholar Anca Giurchescu calls "the use and abuse of folk dance" (personal communication, Feb. 25, 1998). An exception is an essay by Sally Ann Ness (1997) in which she contrasts the use of traditional movement vocabulary in a Philippine ballet company and those same movements as performed by Bayanihan, the Philippine State Dance Ensemble. Another useful monograph which touches upon the subject of a specific dance company (Tanec of Macedonia) is the work of Dunin and Visinski (1995).

5. I am grateful to Andriy Nahachewsky for illustrating this point so well in his articles $(1994,1995)$.

6. For example, Professor Ankica Petrovic stated that she served on committees that selected groups to appear in the Smotra Folklora, a prestigious annual festival held in Zagreb, Croatia. Participant groups, in addition to the honor of appearing in the festival, sometimes received important perquisites for their village such as electrification and paved roads. Committee members often made suggestions or ordered village groups to shorten their presentations or to dance in semi-circles rather than closed circles in order for the audience to be more interested (personal communication, November 3, 1997).

7. Another genre of folk dance, which merits a full study, is the recreational folk dance movement of the United States of the period 1940-1990 in which thousands of Americans were taught a large repertoire of European folk dances by teachers of varying degrees of expertise. (Occasional novelty dances from Japan, Africa, or the Middle East were taught, as well as a number of highly stylized Mexican dances which were also found in the repertoires of the folk dance clubs, as shown in the records of dances taught at folk dance camps. These same sources show that the overwhelming repertoire was composed of dances of European origin. These latter were popular for their patterned quality and reflected the distant origins of the largely middle-class European backgrounds of the American dancers.) The focus for the average recreational folk dancer was to learn many dances from many contrasting regions. The result was that recreational folk dance hobbyists, while learning many dance forms, movements, and steps, rarely acquired the stylistic characteristics manifest by dancers in "the field." (There were notable exceptions to this. A few individuals so "internalized" a new dance tradition, for example Greek or Hungarian, that they sometimes also acquired a native command not only of the dance tradition, but also of the language and other aspects of their "adopted" culture. A few individuals even changed their names and moved to the country of their specific interest.) The dances learned by recreational folk dancers were generally of a three-minute duration, due to the constraints of existing recordings, whereas in the field such a dance, accompanied by native musicians, might last many times that long and never be played in the exact same way twice. The instructions for these dances were "standardized" by such institutions as the California Folk Dance Federation, which maintained a committee of individuals in charge of this process, so that wherever a folk dance hobbyist chose to dance she or he could be assured that the dances they learned would be performed in exactly the same way in every venue visited. In spite of these efforts, complaints circulated that the people in such and such a club did not dance in the "proper" way. The "proper" way did not indicate how the dance might have been performed in the field, but whether it was according to the standardized instructions. Such insistence on standardization stands in stark contrast to the movement practices found in the field where people largely dance with spontaneity and a degree of improvisation that would be impossible to teach in the classroom/studio settings 
in which most recreational folk dancing is taught.

The 1960 s ushered in a nostalgic attempt to create communal ties, and the folk dance movement reflected this social movement. Young people poured into folk dance clubs, particularly those which featured dances from the Balkans with their communal line and circle dances. The older folk dance hobbyists, who preferred dancing in heterosexual couples, largely avoided participating in the communal dances, creating a generational split in the folk dance movement.

8. Andriy Nahachewsky points out that many individuals in the field also leam from professional teachers and perform dances from neighboring regions, and even sometimes dances from other ethnic groups outside the nation-state (personal communication, March 1998). This certainly tallies with my observations: i.e., the repertoire of the Uzbek State Company Bahor included dances of Egypt, India, and Vietnam as well as those of neighboring republics. A second point is that presentations from the field seen in festivals often feature dances that were popular generations ago and that no longer exist "natively" with the generation that currently performs it. This was the case for dances from Medimurje, Croatia in the Smotra Folklora. The dances had to be resuscitated for purposes of performing "old, traditional dances" required by the Smotra committee rather than the polkas and waltzes which had been in vogue for at least a century.

9. While traveling and conducting research in Central Asia and Azerbaijan, professional dance companies and training schools I saw (koreograskii instituti) would perform their formal dance routines and then, following the presentation, would come into the audience and encourage everyone to dance. At this point they all reverted to performing the social dance native to all of the urban Iranian culture sphere, solo improvised dance (Shay 1997).

10. For example, when the villagers of Khorasan province of Iran appeared in dances in an exhibit in the capital city, Tehran, to acquaint the city dwellers with these dances, the dances appeared better rehearsed, but all other aspects of the danceformations, steps and figures, music and costumes were not altered and were the same as the vernacular tradition (film: Dances of Khorasan).

11. Deborah L. Smith (1991) cites the Ballet Folklorico as a catalyst for the popularity of Mexican folk dancing performances in California.

12. Baroque dance historian Wendy Hilton notes: "In a seventeenth-century court ballet, Louis XIV was usually the central figure of the performance, his roles reflecting his deification; the King's most famous identification was with the Greek sun-god Apollo, a role he danced many times" $(1981,7)$.

13. The Kolo Ensemble depicted the Gypsies of the Vojvodina area (north-central Serbia) in two highly cliche-ridden choreographies which make clear that the Gypsies are childlike, over-sexed, decadent, indolent people. In fact, the parallels of characterization with blacks in minstrel shows is striking. (See the video tapes Kolo and Jugoslavija u pesmi $i$ igri.)

14. Recent visits of the Moiseyev Company (1996) and the Georgian State Dance Company (1998) suggest that, regarding these companies and theit repertoires, little has changed from the performances given prior to 1989 .

15. As an artistic director of a dance company which represents various cultures and ethnicities, I have been approached by audience members requesting inclusion of the dances of their ethnicity. For example, Assyrians question me as to why I have not included their dances in our repertoire. The answer to such a question is often either financial, a lack of sufficient research materials, or problems with finding proper music, etc. However, it is important to stress that the pleas for inclusion in our repertoire by individuals representing a wide variety of ethnicities from the areas that my non-official company, the AVAZ International Dance Theatre, represents, are constant. The pressure for inclusion in a state-sponsored company must be even more acute.

16. Knowledgeable observers of the Reda Company of Egypt concur with this assessment. Lois al Faruqi, scholar of dances from the Islamic world, commented: "In the Middle East, recent attempts at programmatic dance by companies like Firqah Rida of Egypt are obvious attempts to imitate an alien tradition (European dance) rather than one native to Egypt" $(1987,6)$

Morroe Berger, former director of the Program in Near Eastern Studies at Princeton University, observed:

As the fame of belly dance spread to the Western world, it became something of an embarrassment to the cultural and political custodians of the East, who began to consider themselves above their own popular arts... This is because the government encourages instead the performance of a sort of folkloric dance that only vaguely resembles the belly dance... . $(1961,43)$ 
See especially Saleh (1979) and Van Nieuwkerk (1995) on this issue.

17. It is beyond the scope of this study to enumerate all of the reasons why historical iconographic materials can be used for an actual historical reconstruction of dances and movement practices in historical periods. I refer the reader to Fermor (1987), Lawler (1964), Shay (1996).

\section{BIBLIOGRAPHY}

Alcedo, Patrick. Personal interview. June 5, 1997.

Al Faruqi, Lois Ibsen. "Dance as an Expression of Islamic Culture." Dance Resource Journal 10/2 (1987): 6-17.

Allworth, Edward. "Restating the Soviet Nationality Question." In Soviet Nationality Problems, edited by Edward Allworth. NY: Columbia University Press, 1971.

"New Central Asians." In Central Asia, edited by Edward Allworth, 527-572. Durham, NC: Duke University Press, 1995.

Anderson, Benedict. Imagined Communities. Rev. ed. London, NY: Verso, 1991.

Arkin, Lisa C. and Marian Smith. "National Dance in the Romantic Ballet." In Rethinking the Sylph: New Perspectives on the Romantic Ballet, edited by Lynn Garafola, 11-68. Hanover and London: Wesleyan University Press, 1997.

Atkin, Muriel. "Religious, National, and Other Identities in Central Asia." In Muslims in Central Asia, edited by Jo-Ann Gross, 46-72. Durham, NC: Duke University Press, 1992.

Balakrishnan, Gopal, ed. Mapping the Nation. London and New York: Verso, 1996.

Ballet Folklorico de Mexico. Souvenir Program. Mexico City, Bellas Artes, n.d.

Ballet Folklorico de Mexico. Souvenir Program. New York, Hurok Publications, 1969-70.

Ballet Folklorico de Mexico. Souvenir Program. 1995.

Bayanihan. Manila, Bayanihan Folk Arts Center, 1987.

Beliaev, Viktor. Central Asian Music: Essays in the History of the Music of the Peoples of the U.S.S.R., edited and annotated by Mark Slobin, translated from the Russian by Mark and Greta Slobin. Middletown, Conn.: Wesleyan University Press, 1975.

Berger, Morroe. Curious and Wonderful Gymnastic. Arab Danse Du Ventre. NY: Dance Perspectives 10 (1961).
Calhoun, Craig, ed. Social Theory and the Politics of Identity. London: Blackwell, 1994.

Critical Social Theory: Culture, History, and the Challenge of Difference. London: Blackwell, 1995.

Carriaga, Daniel. "Ballet Folklorico de Mexico: Controlled Creativity, Styled Authenticity." Los Angeles Times (February 1, 1969): F1.

Cheremetievskaya, Natalia. La Revelation de la Danse: Ensemble de Danses Folkloriques de I'U.R.S.S. sous la Direction de Moisseev. Moscow: Novosti, n.d

Chudnovskii, Mikhael A. Folk Dance Company of the U.S.S.R. Igor Moiseyev, Art Director. Moscow: Foreign Languages Publishing House, 1959.

De Warren, Robert and Peter Williams. "Discovery in Persia." Dance and Dancers (January 1973): 2832

Dunin, Elsie Ivancic and Stanimir Visinski. Dances in Macedonia: Performance Genre: Tanec. Skopje, Tanec ensemble, 1995.

Eley, Geoff and Ronald Grigor Suny, eds. Becoming National. Oxford: Oxford University Press, 1996.

Fermor, Sharon. "On the Question of Pictorial 'Evidence' for Fifteenth-Century Dance Technique." Dance Research 2 (Autumn 1987): 18-32.

Giurchescu, Anna. "Power and the Dance Symbol and its Socio-Political Use" (Keynote paper). In Proceedings. 17th Symposium of the Study Group on Ethnochoreology. Dance and its Socio-Political Aspects: Dance and Costume, edited by Irene Loutzaki, 15-22. Nafplion, Greece: Peloponnesian Folklore Foundation/International Council for Traditional Music, 1994.

Personal communication. Feb. 25, 1998.

Herzfeld, Michael. Cultural Intimacy: Social Poetics in the Nation State. London: Routledge, 1997.

Hilton, Wendy. Dance of Court \& Theater:The French Noble Style 1690-1725. Princeton, NJ: Princeton University Press, 1981. 
Hobsbawm, Eric and Terence Ranger, eds. Invention of Tradition. Cambridge: Cambridge University Press, 1983.

Hoerburger, Felix. "Once Again: On the Concept of 'Folk Dance."' Journal of the International Folk Music Council 20 (1968): 30-31.

Hutchinson, John and Anthony D. Smith, eds. Ethnicity. Oxford: Oxford University Press, 1996.

Ilieva, Anna. "Bulgarian Folk Dance in the Past 45 Years." In Proceedings. 17th Symposium of the Study Group on Ethnochoreology. Dance and its SocioPolitical Aspects: Dance and Costume, edited by Irene Loutzaki, 35-38. Nafplion, Greece: Peloponnesian Folklore Foundation/International Council for Traditional Music, 1994.

Jankovic, Ljubica and Danica. Narodne Igre. 8 vols. Beograd: Prosveta, 1934-1964.

Karimova, R. Ferganskii tanets (Ferghana Dance). Tashkent : Literatura i Iskusstvo, 1973.

. Khorezmiskii tanets (Khorazmian Dance). Tashkent: Literatura i Iskusstvo, 1975.

Bukharskii tanets (Bukharan Dance). Tashkent: Literatura i Iskusstvo, 1977.

Tantsy Ansambl'a Bakhor (Dances of the Bakhor Ensemble). Tashkent: Literatura i Iskusstvo, 1979.

Karomatov, F. and N. Nurdzhanov. Muzikal'noe Iskusstvo Pamira (Musical Art of the Pamirs). Moscow: Vsesouiuznoe Izdatel'stvo Sovetskii Kompozitor, 1986.

Kealiinohomoku, Joann Wheeler. "Folk Dance." In Folklore and Folklife: an Introduction, edited by Richard Dorson, 381-404. Chicago: University of Chicago Press, 1972.

Lawler, Lillian. Dance in Ancient Greece. Middletown, CT: Wesleyan University Press, 1964.

Libman, Lillian. Moiseyev Dance Company. Souvenir Program. NY: McTaggart-Wolk, Inc., 1986-1987.

Ljevakovic, Zvonko. Personal interview. Sept. 28, 1967.

Mahalli Dancers of Iran. Program of Tour of the United States, 1976.

Mazo, Margarita. "Forward." Book VI: The Soviet Union. In JVC Video Anthology of World Music and Dance. Tokyo: Victor Company of Japan, Ltd., 1988.

Misiunas, Romuald and Rein Taagepera. Baltic States,
Years of Dependence 1940-1990. Berkeley: University of California, 1993.

Motyl, Alexander J. Sovietology, Rationality, Nationality. NY: Columbia University Press, 1990.

Nahachewsky, Andriy. "National Standards Versus Social Traditions in Ukrainian Dance." In Proceedings. 17th Symposium of the Study Group on Ethnochoreology. Dance and its Socio-Political Aspects: Dance and Costume, edited by Irene Loutzaki, 73-81. Nafplion, Greece: Peloponnesian Folklore Foundation/International Council for Traditional Music, 1994.

. "Participatory and Presentational Dance as Ethnochoreological Categories." Dance Research Journal 27/1 (Spring 1995): 1-15.

. Personal communication. March 1998.

Ness, Sally Ann. "Originality in the Postcolony: Choreographing the Neoethnic Body of Philippine Dance." Cultural Anthropology 2/1 (February 1997): 65-108.

Ozturkmen, Arzu. "Folk Dance and Nationalism in Turkey." In Proceedings. 17th Symposium of the Study Group on Ethnochoreology. Dance and its SocioPolitical Aspects: Dance and Costume, edited by Irene Loutzaki, 83-86. Nafplion, Greece: Peloponnesian Folklore Foundation/International Council for Traditional Music, 1994.

Petrovic, Ankica. Personal communication. Nov. 3, 1997.

Phelan, Peggy. Unmarked, the Politics of Performance. London and NY: Routledge, 1993.

Saleh, Magda Ahmed Abdel Ghaffar. Documentation of the Ethnic Dance Tradition of Egypt. Ph.D. Dissertation, New York University, 1979.

Shay, Anthony. "Limitations of Iranian Iconographic Sources for the Development of Historical Evidence of Iranian Dancing." Proceedings, 173-186. Society of Dance History Scholars, 1966.

Choreophobia: Iranian Solo Improvised Dance in the Southern California Diaspora. Ph.D. Dissertation, University of Califomia, Riverside. Ann Arbor: University Microfilms, 1997.

Smith, Deborah L. "Mexican Folk Dance in California: A Summary of the Cause and Effects of the Rise in Popularity of Mexican Folk Dancing, 19401990." UCLA Journal of Dance Ethnology (1991): 68-77.

Stratou, Dora. Greek Dances: Our Living Link with 
Antiquity. Athens: no publisher listed, 1966.

Strinati, Dominic. Introduction to Theories of Popular Culture. London and New York: Routledge, 1995.

Swift, Mary Grace. Art of the Dance in the U.S.S.R. Notre Dame: Indiana University of Notre Dame Press, 1968.

Tkachenko, Tamara. Narodny Tanets (Folk Dance). Moscow: Iskusstvo, 1954.

Van Nieuwkerk, Karin. A Trade Like Any Other: Female Singers and Dancers in Egypt. Austin, TX: University of Texas, Austin, 1995.
Urban, Greg and Joel Sherzer. "Introduction: Indians, Nation-States, and Culture." In Nation-States and Indians in Latin America, 1-18. Austin: University of Texas, 1991.

Zemtsovsky, Izaly and Alma Kunanbaeva. "Communism and Folklore." In Folklore and Traditional Music in the former Soviet Union and Eastern Europe, edited by James Porter, 3-23. Los Angeles: Department of Ethnomusicology, University of California, 1997.

\section{VIDEOCASSETTES}

A najmilsze jest Mazowsze is the nicest. Sarasota, FL: Polart, 1971.

Ballet Folklorico De Mexico de Amalia Hernandez. Mexico City: Qualli, 1989.

Dances of Khorasan. Tehran, Iran: Ministry of Information, n. d.

Hrvatski Narodni Plesovi (Croatian Folk Dances). Zagreb: TVZ (Televizija Zagreb), 1986.

In Concert... The Bakhor Ensemble. Seattle: Uzbek Dance Society, 1989.

Jugoslavija u pesmi i igri (Yugoslavia in song and dance). Beograd: Televizija Beograd, n. d.

JVC Video Anthology of World Music and Dance (30 videocassettes). 1988.

Kolo, Ansambl Narodnih Igara. Yugoslav National Ballet. Beograd: RTB (Radio-Televizija Beograd), 1987.
Lado I and II, Professional Folk Dance Ensemble of Croatia Triesen/via Switzerland: IVS, 1989.

Moiseyev Dance Company: A Gala Evening. NY: View Video, 1987.

Polish Folk Dance \& Songs. Sarasota, FL: Polart, 1995.

Rang-a-rang: raqs-ha va avaz-ha-ye mahhali-ye iran (Variety: folk dances and songs of Iran). Tarzana, CA: Pars Video \#125, n. d.

Rags-ha-ye mahalli (Folk Dances). Tarzana, CA: Pars Video \#124, n. d.

Russian Folk Song and Dance. West Long Beach, NJ: Kultur, n.d.

Tanec. Denver 1956. Denver: Harold Ryan, 1969.

Village Dances of Yugoslavia (Jugoslovenski narodni plesovi). (Alpha Video.) Jadran Film, 1948. 